EASTERN REVIEW 2019, T. 8

Artem Karateev

(iD https://orcid.org/0000-0002-8930-8807

Lomonosov Moscow State University, Moscow, Russia

Faculty of Political Science

e-mail: artem.karateev@gmail.com

\title{
Stability and economic freedom in the countries of Central and Eastern Europe: Quantitative analysis
}

\begin{abstract}
Exploring the stability of states and political systems is of interest to scientists and politicians all around the world. One of the most important questions in this field is the question of the relationship between stability and freedom.

This paper considers the relationship between economic freedom and stability with regards to the example of countries of Central and Eastern Europe. The study uses quantitative analysis and the operationalisation of economic freedom through the Index of Economic Freedom (IEF); furthermore, stability is studied through the Fragile States Index (FSI), and the Political Stability and Absence of Violence/Terrorism Index (PSI).

The analysis reveals a strong correlation between economic freedom and stability. According to linear regression models obtained by the author, economic freedom has a strong impact on stability. Models show that most of the components of IEF increase stability, whilst some components decrease it. This means that the same factors affect economic freedom and stability in different ways. In particular, taxes have a very positive effect on stability. At the same it is obvious that taxes reduce economic freedom. This fact allows us to resolve the existing contradictions among politicians and scientists, who differently assess the impact of economic freedom on stability. It may be stated that whilst economic freedom has in general a strong positive effect on stability, it can also have a negative effect.
\end{abstract}

Keywords: stability, political stability, economic freedom, data analysis. 


\section{Introduction}

Issues of social and political stability are widely discussed around the world. Western political tradition connects stability with freedom, liberal values, and democracy. While authors from countries with a strong authoritarian tradition, on the contrary, argue that stability can be ensured through control and centralisation.

A striking example of the Western approach is President Bush's Second Inaugural Address (2005) which proclaimed the idea of global stability through liberty. This idea is supported both by considerations that democracies are more peaceful than other regimes in foreign policy, and conclusions that countries with a higher level of freedom are more stable. There is a vast bibliography on how ensuring rights and freedoms affects economic development and determines economic and political stability. This tradition is well known thanks to such names as F. Hayek (1944, 1973), M. Friedman (1962), L. von Mises (1952) and more modern authors like D. Acemoglu and J. Robinson (2012).

In modern Russia, many scholars and politicians believe that conservative anti-liberal policies are needed to achieve stability and provide social progress. This tradition continues from at least the second half of the $19^{\text {th }}$ century (Shiriniants, 2015). A high level of freedom (both political and economic) is perceived as a risk factor. In addition, at the level of mass consciousness, Russia's political and economic instability of the late $80 \mathrm{~s}$ and $90 \mathrm{~s}$ is associated with the spread of liberal ideas at that time. This naturally discredits the ideas of freedom, while conservative ideas find support among Russians. Interest in conservative methods of ensuring stability is also fuelled by the Chinese development experience, where stability (in the system of priorities) is placed above rights and freedoms.

At the same time, the flip side of stability is also being discussed. Although it is said that stability is crucial for growth, sometimes stability does not trigger any growth. Accordingly, B. Shepherd (2010), in the example of African countries, demonstrates the essential contradictions of stability. On the one hand, the African states that have achieved high growth rates are stable, because stability means a predictable political environment, which in turn attracts investment, both internally and from outside. On the other hand, some African states with remarkably stable political systems do not demonstrate high performance. The fact that stable political regimes turn out to be less effective is confirmed by other modern studies (see for example Bueno de Mesquita et al., 2003). An analysis of the literature available shows, therefore, that the question of the relationship between freedom and stability has not yet been answered and requires further research.

In this paper, we want to focus on the relationship between economic freedom and stability in the countries of Central and Eastern Europe. These countries, 
being in geographic proximity, share common historical and cultural features and nevertheless demonstrate different approaches both to ensuring economic freedom and stability.

A preliminary hypothesis of this work is the assumption that there is a medium or even strong correlation between economic freedom and stability. At the same time various components of economic freedom may have different effects on stability. Some components may increase it, while others may decrease it. Thus, the political system must keep a balance between freedom and stability, taking into account the need to ensure the ability of the system to change and develop. The historical and cultural proximity of the studied European countries and the proximity of the social practices of their citizens, should level the influence of cultural factors that explain the differences in the inferences obtained in different cross-country studies.

\section{Operationalisation/Measuring freedom and stability}

For the operationalisation of economic freedom we will use the Index of Economic Freedom (IEF), annually presented by The Wall Street Journal and The Heritage Foundation. The IEF has a $0-100$ scale and 12 components that are separately evaluated. Each component has a value of between 0 and 100. These components are organised into 4 categories presenting 4 pillars of economic freedom - Rule of Law, Government Size, Regulatory Efficiency, and Market Openness. The resulting IEF for a country is calculated as an average value of 12 components. So it is supposed that all the components have equal weight in constructing economic freedom. A high IEF indicates a free economy while a low score indicates an unfree (or repressed) economy.

Stability will be operationalised by using the Fragile States Index (FSI), annually presented by The Fund for Peace. The FSI also has 12 components including social, economic, political and military indicators. Each component has a value of between 0 and 10. The resulting FSI for a country is calculated as an arithmetic sum of 12 components without weighting them. Thus all the components are claimed to be of equal importance for evaluating stability. The higher the value of the FSI, the more fragile is state.

In addition, the Political Stability and Absence of Violence/Terrorism Index (PSI) will be used to operationalise stability. The PSI is one of the World Governance Indicators collected by The World Bank. This index measures perceptions of the likelihood that the government will be destabilised or overthrown by unconstitutional or violent means, including politically-motivated violence and terrorism. It has a scale with a minimum equal to -2.5 and maximum equal to 2.5 . 
The FSI is picked as a more comprehensive measure, vulnerable to the economic situation; whilst the PSI is picked as being more vulnerable to political risks.

\section{Analysis}

At the first stage of the study, the hypotheses that there is a medium or strong correlation between economic freedom and stability was tested.

For the analysis we took a dataset for 8 countries of Central Europe (Austria, The Czech Republic, Germany, Hungary, Poland, The Slovak Republic, Slovenia, and Switzerland) and 7 countries of Eastern Europe (Belarus, Estonia, Latvia, Lithuania, Moldova, Russia, and Ukraine). Since there are various interpretations of the borders of Central and Eastern Europe, we took as a basis one of the most popular interpretations according to the CIA World Factbook. (Note: Liechtenstein was excluded from the study, since the data on it were incomplete.)

The correlation coefficients between IEF and stability indexes (i.e. FSI and PSI) were calculated using annual data. It can be seen from Table 1, that IEF is strongly negatively correlated with FSI. This means that countries with a high level of economic freedom are supposed to be less fragile than countries with low level of economic freedom. Conversely, IEF is strongly positively correlated with PSI, illustrating that countries with high level of economic freedom are supposed to be more politically stable than countries with low level of economic freedom. As it is seen, both these tendencies are stable over time.

Table 1. Correlation coefficients between IEF and stability indexes

\begin{tabular}{|c|c|c|}
\hline Year & Fragile States Index & Political Stability Index \\
\hline 2013 & -0.840 & 0.864 \\
\hline 2014 & -0.868 & 0.816 \\
\hline 2015 & -0.850 & 0.811 \\
\hline 2016 & -0.868 & 0.813 \\
\hline 2017 & -0.767 & 0.782 \\
\hline
\end{tabular}

Source: based on author's calculations.

These results show that economic freedom has a crucial importance for a state's stability. The regression model for 2017 (obtained using the Ordinary Least Squares (OLS) method) demonstrates that a 1.0 point change in IEF leads to an approximate 1.4863 points change in the FSI:

$$
\mathrm{FSI}=-1.4863 \mathrm{IEF}+147.99 .
$$




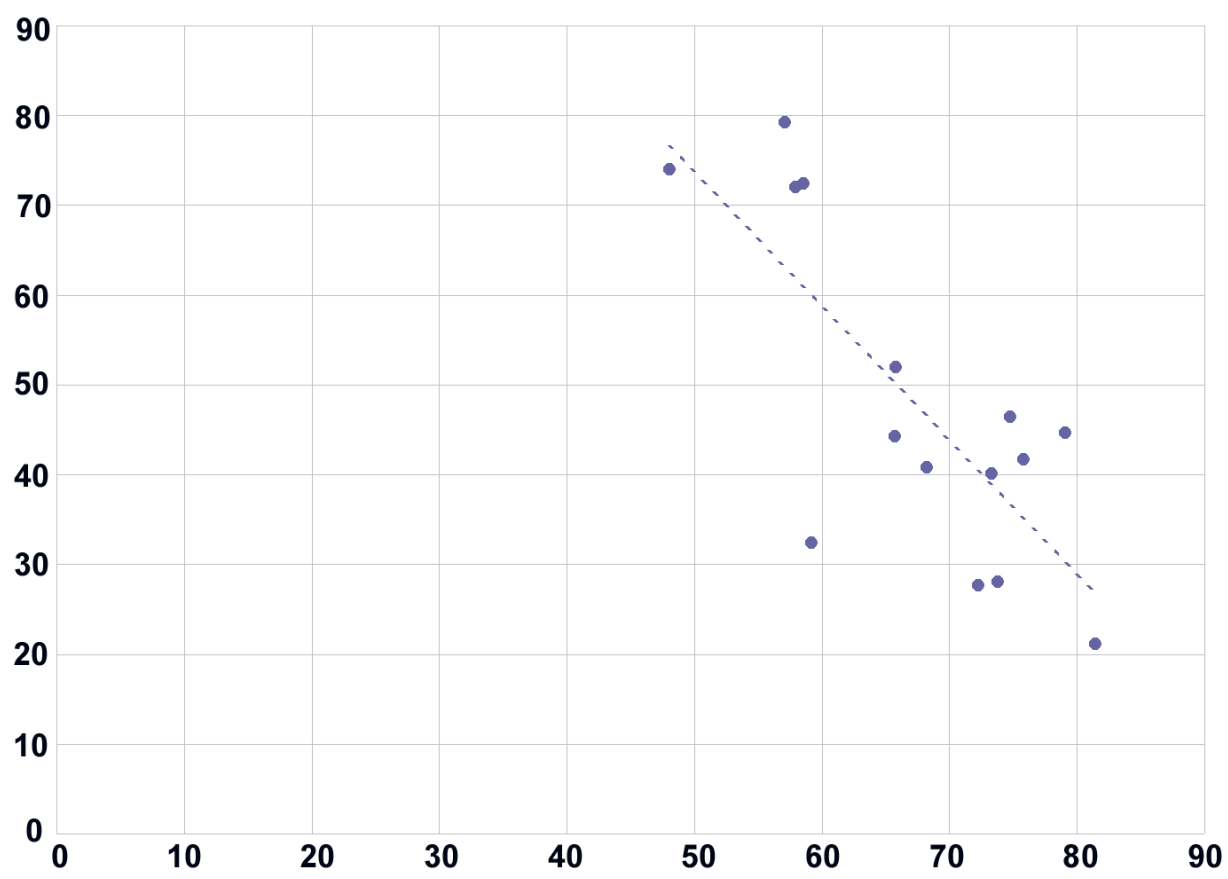

Figure 1. Scatter plot of IEF and FSI with OLS regression line (2017)

Source: based on author's calculations.

Only a few countries deviate significantly from the trend line. Deviations of the real FSI values from the trend line are presented in Table 2. Slovenia has the greatest deviation -27.6 (the minus shows that the real fragility of the state is less than it is expected by the model). Similar results can be obtained for other years (2013-2016).

Table 2. The real values of the IEF and FSI and the difference between the real value and the expected value of the FSI (2017)

\begin{tabular}{|l|c|c|c|}
\hline \multicolumn{1}{|c|}{ Country } & $\begin{array}{c}\text { Index of Economic } \\
\text { Freedom }\end{array}$ & $\begin{array}{c}\text { Fragile States } \\
\text { Index }\end{array}$ & $\begin{array}{c}\text { Difference between real value } \\
\text { and expected value of FSI }\end{array}$ \\
\hline \multicolumn{1}{|c|}{1} & 2 & 3 & 4 \\
\hline Austria & 72.3 & 27.7 & -12.9 \\
\hline Czech Republic & 73.3 & 40.1 & 1.1 \\
\hline Germany & 73.8 & 28.1 & -10.2 \\
\hline Hungary & 65.8 & 52 & 1.8 \\
\hline Poland & 68.3 & 40.8 & -5.7 \\
\hline Slovak Republic & 65.7 & 44.3 & -6.0 \\
\hline
\end{tabular}


Table 2 (cont.)

\begin{tabular}{|l|c|c|c|}
\hline \multicolumn{1}{|c|}{1} & 2 & 3 & 4 \\
\hline Slovenia & 59.2 & 32.4 & -27.6 \\
\hline Switzerland & 81.5 & 21.1 & -5.8 \\
\hline Belarus & 58.6 & 72.4 & 11.5 \\
\hline Estonia & 79.1 & 44.7 & 14.2 \\
\hline Latvia & 74.8 & 46.4 & 9.5 \\
\hline Lithuania & 75.8 & 41.7 & 6.3 \\
\hline Moldova & 58.0 & 72 & 10.2 \\
\hline Russia & 57.1 & 79.2 & 16.1 \\
\hline Ukraine & 48.1 & 74 & -2.5 \\
\hline
\end{tabular}

Source: based on author's calculations.

Regression model of IEF and PSI for 2017 is:

$$
\mathrm{PSI}=0.0667 \mathrm{IEF}-4.0905 .
$$

It is important to compare the effect of the IEF on the FSI with the effect of the IEF on the PSI. In order to make this comparison, the fact that the FSI and the PSI have different scales must be taken into account. As a result it can be seen that the effect of the IEF on the PSI is slightly stronger than the effect of the IEF on the FSI (by the power of 1.08).

At the next stage of the study, we will try to understand what effect each of the IEF components has on stability indicators.

As it was mentioned above, the IEF includes 4 categories of components - Rule of Law (RL), Government Size (GS), Regulatory Efficiency (RE), and Market Openness (MO). Using data for the 2017, and the OLS method, we can get a multiple regression model for the FSI:

$$
\mathrm{FSI}=-0.454 \mathrm{RL}+0.356 \mathrm{GS}-0.224 \mathrm{RE}-0.576 \mathrm{MO}+107.021 .
$$

The regression equation shows that a 1.0 point increase of $\mathrm{RL}, \mathrm{RE}, \mathrm{MO}$ decreases the fragility of a country by $0.454,0.224$ and 0.576 points respectively. Whereas a 1.0 point increase of GS increases the fragility of a country by 0.356 .

The negative correlations between the FSI and RL mean that an increase of government integrity and judicial effectiveness, as well as the protection of property rights, should have a positive effect on stabilisation. The negative correlations between the FSI and RE indicate that an increase of business freedom, labor freedom, and monetary freedom leads to stabilisation. However, it is MO which has the greatest influence on the FSI, which includes trade freedom, investment 
freedom, and financial freedom. The positive correlation between the FSI and GS means that an increase of such components as Tax Burden, Government Spending, and Fiscal Health should decrease stability. Low values of these components mean that the situation with tax burden, government spending, and fiscal health is not "friendly" for business; that taxes and government spending are high, and therefore the budget deficit and country's debts are rising. Thus the higher the taxes and spending, and deficit and debts, the higher -1.4863 IEF + 147.99.

The presented regression model has a very good explanatory power: $\mathrm{R}$-squared is equal to 0.926 . It means that RL, GS, RE and MO are able to explain the $92.6 \%$ variability of the FSI.

Considering the correlation between the FSI and indicators from the GS group in Table 3, i.e. Tax Burden (TB), Government Spending (GSp), and Fiscal Health (FH), we can see that the greatest correlation is between the FSI and TB. Correlations between other components and the FSI are rather weak. It may be therefore inferred that GSp and FS do not have a significant effect on state fragility in Central and Eastern Europe. Unfortunately this result cannot be proved using data for other time periods, as the TB component was only added to the calculation formula of the IEF in 2017.

Table 3. Correlation coefficients between the components of Government Size and the FSI (2017)

\begin{tabular}{|c|c|}
\hline Component & Fragile States Index \\
\hline Tax Burden & 0.641 \\
\hline Government Spending & 0.172 \\
\hline Fiscal Health & 0.162 \\
\hline
\end{tabular}

Source: based on author's calculations.

The importance of taxes in ensuring stability can be explained by the fact that taxes are used to implement various measures and projects designed to reduce the degree of a country's instability. For example, taxes can be used to regulate the macroeconomic situation, to reduce tensions in society, to provide social assistance and to strengthen security forces, etc.

Using all 12 components of the IEF, we can obtain a comprehensive regression model with even higher explanatory power than the previous model with 4 predictors:

$$
\begin{gathered}
\mathrm{FSI}=-0.333 \mathrm{PR}-0.039 \mathrm{JE}+0.165 \mathrm{GI}+1.072 \mathrm{~TB}-0.431 \mathrm{GSp}-0.054 \mathrm{FH}+ \\
0.149 \mathrm{BF}-0.173 \mathrm{LF}-0.717 \mathrm{MF}-1.775 \mathrm{TF}+0.227 \mathrm{IF}-0.008 \mathrm{FF}+198.952 .
\end{gathered}
$$

Where PR stands for Property Rights, JE for Judicial Effectiveness, GI for Government Integrity, TB for Tax Burden, GSp for Government Spending, FH for Fiscal Health, BF for Business Freedom, LF for Labor Freedom, MF for 
Monetary Freedom, TF for Trade Freedom, IF for Investment Freedom, and FF for Financial Freedom.

$\mathrm{R}$-squared for this model is equal to 0.983 . It means that the combination of 12 components is able to explain the $98.3 \%$ variability of the FSI. It can be seen that most of the components reduce state fragility, except GI, TB, BF, and IF. Due to a shortage of data, statistical significances of model coefficients are far from $5 \%$, so detailed discussion about these coefficients is unnecessary.

Based on the data for the years 2017, 2018, 2019 a more sophisticated regression model can be obtained (see Table 4). As was mentioned above, the 12 components model of the IEF has been used from 2017 and there is no appropriate data for the previous period. So dataset is scarce and it leads to the fact that many of the obtained model coefficients do not have the necessary statistical significance.

Table 4. Coefficients of regression model (2017-2019)

\begin{tabular}{|l|c|c|}
\hline \multicolumn{1}{|c|}{ Component } & Coefficient & P-value \\
\hline Constant & 131.294 & 0.000 \\
\hline Property Rights (PR) & -0.617 & 0.001 \\
\hline Judicial Effectiveness (JE) & 0.126 & 0.217 \\
\hline Government Integrity (GI) & -0.080 & 0.513 \\
\hline Tax Burden (TB) & 0.704 & 0.000 \\
\hline Government Spending (GSp) & -0.242 & 0.017 \\
\hline Fiscal Health (FH) & -0.001 & 0.985 \\
\hline Business Freedom (BF) & 0.225 & 0.271 \\
\hline Labor Freedom (LF) & -0.202 & 0.007 \\
\hline Monetary Freedom (MF) & -0.395 & 0.014 \\
\hline Trade Freedom (TF) & -0.764 & 0.026 \\
\hline Investment Freedom (IF) & 0.102 & 0.428 \\
\hline Financial Freedom (FF) & -0.058 & 0.612 \\
\hline
\end{tabular}

Source: based on author's calculations.

Nonetheless, with the increase of the dataset, we can expect that the situation with some of the components will not change in general. As was already discussed, TB is expected to have a strong positive effect on the FSI.

Freedoms and rights, apparently, should reduce the FSI. Actually such components as PR, LF, MF, TF, FF have negative coefficients. At the same time BF and IF have positive coefficients though these coefficients are not high and are not significant statistically. JE as an indicator of the quality of institutions should also have a negative impact on the FSI, but in fact it has a positive coefficient, although 
it is small and does not have statistical significance. GI in theory can have both positive and negative effects on the FSI. On the one hand, irregular payments and bribes and cronyism, and other forms of political corruption, negatively affect the image of authorities and politicians. That said, cronyism and patronage can make elites more cohesive and stable.

Government Spending (GSp) includes the costs of maintaining the authorities themselves (which depends on their size), as well as the costs of state projects and programs. Low values of GSP imply high costs. High expenditures on maintaining the authorities can deprive the economy of the necessary funds and cause discontent among the population. At the same time, government investments in infrastructure, scientific research, human capital, and national defence have a positive effect on stability. However, it is supposed by the authors of the IEF that government investments are not so efficient as private sector investments. In the model for 2017, as well as for 2017-2019, GSp has a negative coefficient, reflecting the fact that government spending in Central and Eastern Europe mainly does not contribute to stabilisation.

Fiscal Health $(\mathrm{FH})$ is derived on the basis of two indicators: the size of the state debt and the size of the state budget deficit. The higher the deficit and debt, the lower the FH value. A large debt and deficit means an increased likelihood of government intervention in the economy: tax changes and other measures that reduce economic freedom. On the one hand, a low debt and small deficit indicate stability in the economy; on the other hand, debt and budget deficit may be the result of policies aimed at social and economic stabilisation. Thus, stability depends not only on the size of the debt and deficit, but also on the purposes funds were used for. Accordingly, this situation is reflected in the fact that FH has a coefficient close to zero, and the coefficient of correlation between FSI and FH is also close to zero (see Table 3).

\section{Conclusion}

Exploring the stability of states and political systems is of interest to scientists and politicians from all parts of the world. And one of the most important questions in this field is the question of the relationship between stability and freedom. This paper considered the relationship between economic freedom and stability using the example of countries of Central and Eastern Europe. Economic freedom is operationalised through the Index of Economic Freedom (IEF), and stability through both the Fragile State Index (FSI), and the Political Stability and Absence of Violence/Terrorism Index (PSI). Comparing states with similar historical and cultural heritage, as well as the proximity of the social practices of their citizens, reduces the impact of cultural and geographical factors. 
The analysis reveals a strong correlation between economic freedom and stability which is confirmed by recent data. According to the linear regression models obtained, economic freedom has a strong impact on stability. Models show that most of the components of IEF increase stability, whilst some components decrease it. This means that the same factors affect economic freedom and stability in different ways. In particular, taxes have a serious positive effect on increasing stability. At the same time, it is obvious that taxes reduce economic freedom. This fact allows us to resolve the existing contradictions among politicians and scientists, who differently assess the impact of economic freedom on stability. It may be stated that whilst having in general a strong positive effect on stability, economic freedom can also have a negative effect.

Since the dataset used is not yet sufficient to obtain a statistically significant model of coefficients it is necessary to continue research, either after the release of a new IEF report, or by expanding the studied region.

The analysis should be useful for scientists and academicians; as well as policy makers.

\section{References}

Acemoglu, D., Robinson, J. (2012). Why Nations Fail. The Origins of Power, Prosperity, and Poverty. New York: Crown Business.

Bueno de Mesquita B., Smith A., Siverson R., Morrow J. 2003. The Logic of Political Survival. Cambridge, Mass.: The MIT Press.

Feng, Y. 1997. Democracy, Political Stability and Economic Growth. British Journal of Political Science 27(3), pp. 391-418.

Fragile States Index. Annual Reports. The Fund for Peace, https://fragilestatesindex.org/ (accessed 25.10.2019).

Friedman, M. 1962. Capitalism and Freedom. Chicago: University of Chicago Press.

Georgiou, M.N., Kyriazis, N., Economou, E.M.L. 2015. Democracy, Political Stability and Economic Performance. A Panel Data Analysis. Journal of Risk \& Control 2(1), pp. 1-18.

Hayek, F. 1944. The Road to Serfdom. Chicago: University of Chicago Press.

Hayek, F. 1973. Law Legislation and Liberty. Rules and Order. Vol. 1. Chicago: University of Chicago Press.

Henriksen, T.H. 2007. American Power after the Berlin Wall. New York: Palgrave MacMillan.

Index of Economic Freedom. Annual Reports. The Heritage Foundation, https://www. heritage.org/index/ (accessed 25.10.2019).

Kuznetsov, I.I., Artamonova, Y.D., Bubnov, A.Y., Karateev, A.Y., Mityaeva O.I., Chernyahovsky, S.F. 2016. Ustoichivost' politicheskih sistem: teoreticheskie modeli i praktichekii opyt. Vestnik Moscovskogo Universiteta. Serija 12. Politicheskie nauki 3, pp. 107-125. 
Mises, L. von. 1952. Planning for Freedom, and Other Essays and Addresses. South Holland: Libertarian Press.

Nelson, M.A., Ram, D., Singh, N. 1998. Democracy, Economic Freedom, Fiscal Policy, and Growth in LDCs: A Fresh Look. Economic Development and Cultural Change 46(4), pp. 677-696.

Political Stability and Absence of Violence / Terrorism Index. Annual Reports. The World Bank, http://info.worldbank.org/governance/wgi/\#home (accessed 25.10.2019).

Shepherd, B. 2010. Political Stability: Crucial for Growth? LSE Ideas Strategic Brief. London School of Economics and Political Science.

Shiriniants, A.A. 2015. «Konservator»: slovo i smysly v russkoi sotsial'no-politicheskoi mysli. Vestnik Moscovskogo Universiteta. Serija 12. Politicheskie nauki 6, pp. 112-124. 